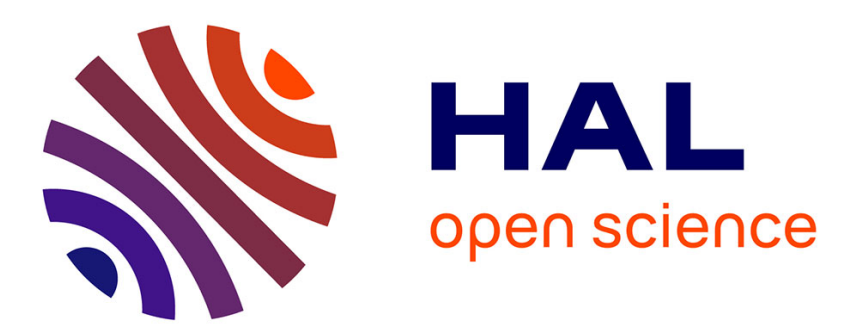

\title{
The effect of thermal treatment on the neuronal cell biocompatibility of SU-8
}

Tiffany Baëtens, Severine Begard, Emiliano Pallecchi, S. Arscott, V. Thomy, Sophie S. Halliez

\section{- To cite this version:}

Tiffany Baëtens, Severine Begard, Emiliano Pallecchi, S. Arscott, V. Thomy, et al.. The effect of thermal treatment on the neuronal cell biocompatibility of SU-8. Materials Today Communications, 2020, pp.101073. 10.1016/j.mtcomm.2020.101073 . hal-02514939

\section{HAL Id: hal-02514939 \\ https://hal.science/hal-02514939}

Submitted on 6 Jan 2021

HAL is a multi-disciplinary open access archive for the deposit and dissemination of scientific research documents, whether they are published or not. The documents may come from teaching and research institutions in France or abroad, or from public or private research centers.
L'archive ouverte pluridisciplinaire HAL, est destinée au dépôt et à la diffusion de documents scientifiques de niveau recherche, publiés ou non, émanant des établissements d'enseignement et de recherche français ou étrangers, des laboratoires publics ou privés. 


\title{
The effect of thermal treatment on the neuronal cell biocompatibility of SU- 8
}

Tiffany Baëtens ${ }^{1}$, Séverine Begard ${ }^{2}$, Emiliano Pallecchi ${ }^{1}$, Vincent Thomy ${ }^{1}$, Steve Arscott ${ }^{1}$, Sophie Halliez ${ }^{2}$

1) Institut d'Electronique, de Microélectronique et de Nanotechnologie (IEMN), CNRS UMR8520, The University of Lille, Cité Scientifique, Avenue Poincaré, 59652 Villeneuve d'Ascq, France

2) Univ. Lille, Inserm, CHU Lille, U1172 - LilNCog - Lille Neuroscience \& Cognition, F59000 Lille, France steve.arscott@univ-lille.fr

sophie.halliez@inserm.fr

\begin{abstract}
Future in vitro life science studies that require in situ functionalities - going beyond the common glass petri dish — can potentially be realized by using microsystems technologies to fabricate bio-microelectromechanical systems (BioMEMS) and laboratory-on-a-chip (LOC). One such material used to construct these microsystems is the commercial photoresist SU-8. Here, the neuronal biocompatibility of SU-8 is examined as a function of its hard-baking thermal treatment. The SU-8 surfaces were non-patterned large uniform thin films-this allowed the biocompatibility and cell adhesion of the SU-8 to be fully tested. In total, 75 SU-8 samples were fabricated for the study using spin-coating and lithography techniques. We observe that a single hard-baking step of $180^{\circ} \mathrm{C}$ for 2 hours coupled with a coating (poly-Dlysine + laminin) is enough to detoxify SU-8 and promote primary cortical cell adhesion and survival up to 28 days in vitro (DIV). Therefore, the protocol described here makes SU-8 surfaces compatible with the development of neuronal networks from primary neural cells.
\end{abstract}

Keywords: SU-8, microsystems, microtechnology, neuronal cells, biocompatibility, hardbaking 


\section{Introduction}

The building, functionalization and characterization of complex in vitro neural networks from primary neural cells has benefited from the development of microsystems dedicated to life sciences such as bio-microelectromechanical systems (bio-MEMS) and laboratory-on-a-chip (LOC) $[1,2]$. This has been achieved by harnessing advantages such as inter alia microscale confinement, environmental control (liquid and gas flow, temperature, surface properties), the parallelization of experiments, and sensors integration [3-6]. Despite the many breakthroughs made possible by the application of microtechnologies to life sciences studies, there are still questions concerning the biocompatibility of the specific materials and their associated technological processes when used with biological materials. Indeed, the fabrication of bioMEMS and LOC requires both the use of structural and functional materials (e.g. glass, silicon, metals, polymers...) and evidently their associated technological processes and associated chemicals (solvents, chemical reagents, strong acids or bases). In the latter case, the chemicals used for manufacturing can be absorbed by the structural materials of the microsystems and can also leave residues on the microsystem which can subsequently interact with living organisms, liquids and gases necessary for cultures. This can occurover very wide time scales from a few minutes to more than several weeks. Given the current relative lack of standardization concerning the building of such bio-MEMS, a systematic study of the biocompatibility of materials (which is performed relatively routinely) and the impact of their associated technological processes (more rarely detailed and studied) is required. Due to the very wide diversity of biological experiments, we would like to underline that fact that it is not possible to define a material or process as being 'universally biocompatible'. Thus, biocompatibility studies must be systematically carried out in the specific context in which the specific bioMEMS will be used.

In this paper we present a simplified processing protocol to improve the photoresist SU8's capability to support direct primary neurons network growth up to 28 days in vitro (DIV).

\section{The photoresist SU-8 in bio-MEMS and LOC for neuronal cell studies}

SU-8 is a versatile thick film negative photoresist [7] which has been used for the fabrication of several micro- and nano- technology-based applications, e.g. microelectromechanical systems (MEMS) [8], high frequency waveguides [9], stretchable technologies [10], and microfluidics [11]. More recently its use in bio-MEMS has considerably expanded [12,13]. In the latter applications, its biocompatibility is an important issue. In this context, we can categorize the use of SU-8 into three different roles: (i) the polymerized SU-8 forms an integral part of the microsystem and the analyte is in contact with the SU-8 [14,15], (ii) the polymerized SU-8 forms an integral part of the microsystem but the analyte is not in 
contact with the SU-8 due to an encapsulation layer [16] or surface functionalization [17], and (iii) the SU-8 is not used as a part of the final system, but is used to make the final systems e.g. a molding step $[18,19]$. In the former and latter cases, the issue of biocompatibility comes from (i) the SU-8 itself and (ii) the previous technological steps where contamination can come from the products used for SU-8 processing. SU-8 photoresist is composed of an epoxy resin, bistriarylsulfonium and sulfonium hexafluoroantimonate salts, pyrolytic carbon [20] and a solvent (either cyclopentanone or gamma-butyrolactone). Its microfabrication processing is welldocumented and involves the use of a developer (1-methoxy-2-propanol acetate) and an isopropanol rinse. It is known that 'hard-baking' at $200^{\circ} \mathrm{C}$ renders the material less chemically reactive [7] and modifies its mechanical properties [21]. Evidently, SU-8 is often used as part of a larger technological process which can involve other photoresists and their associated processing chemicals e.g. other solvents, acids, and bases.

Being able to use polymerized SU-8 as a structural material for bio-MEMS and LOC dedicated to neuronal development would allow one to extend the scope of what can be presently done. However, when compiling data from the literature, one can see culturing primary neural cells on SU-8 remains relatively controversial. Biocompatibility of SU-8 was previously validated in vitro using mouse fibroblasts in a contactless assay [22], human fibroblasts cultured beside SU-8 microprobes [22] and grown on oxygen plasma-treated bare SU-8 [23], primary glial cells (peripheral glial cells and astrocytes) cultured beside SU-8 microprobes [22] and grown directly on bare nanostructured SU-8 [24], rat glial cell lines grown on bare SU-8 [25] and in a contactless assay[26] and rodent and human neuronal cell lines recruited by dielectrophoresis on bare microstructured SU-8 [27], grown on poly-L-lysinecoated flat or nanostructured SU-8 and even directly grown on bare nanostructured SU-8 [2830]. However, a limitation commonly seen in these findings is the experimental duration. Depending on the neuronal type and the cell density, primary neurons require a period ranging from several days to several weeks to develop into mature networks [31]. The experiments mentioned beforehand were conducted over at most 7 days. Moreover, if immortalized neuronal cell lines can be induced to differentiate into cells sometimes described as neuron-like cells, these cells are not representative of primary neurons [32,33] and cannot be used to grow neuronal networks. Primary neuronal cells are generally more sensitive [34], although some notable exceptions have been described [35]. Therefore, biocompatibility tests performed with neuronal cell lines could be irrelevant for primary neuronal cells. Indeed, biocompatibility of non-hard-baked SU-8 proved to be very poor for primary cortical neurons [36] and hippocampal neurons [27]. Heat treatment [27,36] and hydroxylation [27] are known to greatly improve the biocompatibility of SU-8 when neuronal cells are not seeded on top of the SU-8 but cultured adjacent to it [36] or when dielectrophoresis is applied to recruit neurons on microstructured 
SU-8 [27]. It should be noted that primary cortical cells, seeded in a microfluidic-MEA device based on polydimethylsiloxane (PDMS) and SU-8 bonding, have been reported to form a functional neuronal network after two weeks of culture. However, in this configuration, cortical cells are not seeded on SU-8 [37]. Dorsal root ganglion (DRG) explants were also cultured in presence of SU-8 microprobes and the latter were observed to sustain the growing of DRGemanating nerve fibers [23]. In the same study, the authors also successfully implanted these microprobes into sciatic nerves of rats - the study lasting for almost one year [23]. However, under these conditions, a substantial degree of maturation was already achieved when the cells came into contact with the SU-8 - hence the ability of SU-8 to support fully the adhesion and development of primary neuronal cells is still questionable. Moreover, assays with HeLa cells (human cell line) [38], the rat adrenal phaeochromocytoma PC-12 cell line [39] and primary neuronal cells $[27,36]$ when seeded directly on top of untreated and bare SU-8 showed poor cell attachment. Plasma activation is reported, which is seen to improve considerably the cell adhesion and their growth [24,36]. Methods currently known to improve primary neuronal cell adhesion on SU-8 are heat treatment + sonication +/- parylene coating + poly-D-lysine coating [36], , structuration +/- poly-L-lysine coating (cell adhesion is better with poly-L-coating) $[28,29,40,41]$ and surface functionalization [42]. As previously indicated, applying dielectrophoresis to recruit primary neurons directly on top of microstructured heat- or hydroxylated-treated SU-8 elicit good cell adhesion and viability for 7 days [27]. It can be noted that rat cortical cells were seeded and cultured successfully for 20 days on a structured surface consisting of SU-8 tower structures, heated at $110^{\circ} \mathrm{C}$ for 3 days then heated in water at $45^{\circ} \mathrm{C}$ for 1 day and coated with poly-L-lysine [40]. But all these processes are time-consuming, can be difficult to integrate with other technical requirements, and/or require materials not available in basic biological labs where the cell culture will be ultimately performed. Here, we tested and validated a simplified processing protocol (hard-baking for 2 hours followed by poly-D-lysine and laminin coating) to treat unstructured SU-8 surfaces in order to make it suitable to support the long-term development of neural cells seeded on it.

\section{Material and methods}

\subsection{Sample processing}

All technological processes for the fabrication of the samples were performed in an ISO $5 / 7$ cleanroom (IEMN). The samples were then sealed and transferred to the biology laboratory (JPARC). Four types of samples were tested: glass with cover glasses having a diameter of 18 mm (Marienfeld Superior, Germany), tissue culture (TC) treated-polystyrene (Corning, USA), PDMS (Dow Corning, USA), and the photoresist SU-8 (MicroChem, USA). The samples were processed or deposited at the bottom of wells in 12-well cell culture plates (Corning, USA). For 
TC treated-polystyrene samples, empty well surfaces were used. The PDMS samples were prepared using a commercially available kit (Sylgard 184, Dow Corning) [43]. The base and curing agent were mixed to a ratio of 10:1, degassed using a rotary pump, molded directly in wells of cell culture plates, and cured in a box oven (Mpemmert GmbH, Germany) at $70^{\circ} \mathrm{C}$ for 2 hours.

For the SU-8 samples, we used circular cover glasses having diameter of $18 \mathrm{~mm}$ as substrates for the SU-8 deposition. SU-8 '2002' was used in order to obtain a thin thickness of resin. The surfaces were spin coated with SU-8 2002 using a commercial spin-coater (Suss MicroTec Lithography GmbH, Germany). A uniform $~ 800 \mathrm{~nm}$ thick SU-8 films is achieved by spin coating at $2000 \mathrm{rpm}$, acceleration of $500 \mathrm{rpm} \mathrm{s}^{-1}$ for $12 \mathrm{~s}$ followed by a pre-exposure bake (prebake) on hotplate at $95^{\circ} \mathrm{C}$ for 2 minutes - the film thickness was verified using commercial surface profiling (Bruker, USA). Taking the substrate material in account, the samples were optimally exposed [44] to UV light (wavelength $365 \mathrm{~nm}$ ) for $5 \mathrm{~s}$ at $10 \mathrm{~mW} \mathrm{~cm}^{-2}$ in a commercial mask aligner (Suss Microtech, Germany) to promote the polymerization. Next, the samples are placed on hotplate at $95^{\circ} \mathrm{C}$ for 2 minutes to achieve polymerization - this is the post-exposure base (PEB). 75 SU-8-based samples were spin-coated and processed for the study using this method.

In order to study the behavior of the neuronal cells seededon the SU-8 surfaces, the samples were divided into 3 groups by varying the 'hard-bake temperature' performed in a box oven at $100^{\circ} \mathrm{C}, 180^{\circ} \mathrm{C}$ and $200^{\circ} \mathrm{C}$ for 2 hours. Finally, the samples were inserted into cell culture plate. The cell culture plate was then closed and initially sterilized under UV light for 1 hour before transportation to the biology laboratory. The samples were then sterilized for a second time under UV light for 15 minutes prior to coating. Table 1 gives a complete list of all samples used in the study plus their individual processing thermal history.

Table 1. List of samples fabricated and used in the study. Their thermal history and processing are given.

\begin{tabular}{|c|c|c|c|c|c|c|}
\hline Sample Ref. & Surface & $\begin{array}{c}\text { Number of } \\
\text { samples }\end{array}$ & Hard-bake & Prebake & PEB & $\begin{array}{c}\text { UV exposure } \\
\left(\mathrm{mJ} \mathrm{cm}^{-2}\right)\end{array}$ \\
\hline Glass & Glass & 33 & $\mathrm{n} / \mathrm{a}$ & & & \\
\hline $\begin{array}{l}\text { TC treated- } \\
\text { Polystyrene }\end{array}$ & $\begin{array}{l}\text { TC treated- } \\
\text { Polystyrene }\end{array}$ & 35 & $\mathrm{n} / \mathrm{a}$ & & & \\
\hline PDMS & PDMS & 20 & & $70^{\circ} \mathrm{C} / 2 \mathrm{hrs}$ & & \\
\hline S1 & SU-8 & 18 & $100^{\circ} \mathrm{C} / 2 \mathrm{hrs}$ & $\begin{array}{c}95^{\circ} \mathrm{C} / 2 \\
\text { mins }\end{array}$ & $\begin{array}{c}95^{\circ} \mathrm{C} / 2 \\
\text { mins }\end{array}$ & 50 \\
\hline $\mathrm{S} 2$ & SU-8 & 30 & $180^{\circ} \mathrm{C} / 2 \mathrm{hrs}$ & $\begin{array}{c}95^{\circ} \mathrm{C} / 2 \\
\text { mins }\end{array}$ & $\begin{array}{c}95^{\circ} \mathrm{C} / 2 \\
\text { mins }\end{array}$ & 50 \\
\hline
\end{tabular}




\begin{tabular}{|c|c|c|c|c|c|c|}
\hline S3 & SU-8 & 17 & $200^{\circ} \mathrm{C} / 2 \mathrm{hrs}$ & $95^{\circ} \mathrm{C} / 2$ & $95^{\circ} \mathrm{C} / 2$ & 50 \\
& & & & $\operatorname{mins}$ & $\operatorname{mins}$ & \\
\hline
\end{tabular}

\subsection{Cell culture}

Each test sample was coated with a mix of Poly-D-lysine $\left(0.5 \mathrm{mg} \mathrm{ml}^{-1}\right.$, Sigma $)$ and Laminin $\left(10 \mu \mathrm{g} \mathrm{ml}^{-1}\right.$, Sigma). Enough volume of coating solution was added per well (around $1 \mathrm{ml}$ ) to totally cover the different surfaces even if water-repellent. The coating solution was applied for 2 hours at room temperature then washed using sterile water (Corning) and air-dried. No additional surface treatment was performed.

Rat primary cortical cells were prepared from 18-days-old Wistar rat embryos-as previously described [45]. The present experimental research has been performed with the approval of an ethical committee (agreement APAFIS\#2264-2015101320441671 from CEEA75, Lille, France) and follows European guidelines for the use of animals. Gestating females (Janvier Labs) were housed in a temperature-controlled $\left(20-22^{\circ} \mathrm{C}\right)$ room maintained on a $12 \mathrm{~h}$ day/night cycle with food and water provided ad libitum. The culture medium was made of Neurobasal (Gibco) supplemented with B-27 (Gibco), Antibiotic-Antimycotic (Gibco) and L-glutamine (Gibco). To generate the results presented here, a total of four different cell culture dissociations were performed from four different litters. The number of viable cells in the cell suspensions was determined through trypan blue exclusion test (Gibco). For each sample, 250000 viable cells were seeded in $1.5 \mathrm{ml}$ culture medium on a total area of $3.5 \mathrm{~cm}^{2}$ so 71400 cells $/ \mathrm{cm}^{2}$. Cultures were kept in a cell incubator (ThermoScientific) at $37^{\circ} \mathrm{C}$ in a $5 \%$ $\mathrm{CO}_{2}$ atmosphere.

\subsection{Cell viability/metabolic activity assay and cytotoxicity/cell death assay}

To assay metabolic activity/number of viable cells, cellular reduction of MTS tetrazolium into formazan was quantified using the CellTiter 96 Aqueous One Solution Cell Proliferation Assay (Promega) following the manufacturer's instructions. Cells grown on coated glass slides were used as a reference. Briefly, reagent was added in each well (1:5 ratio) and the cells were incubated three hours (at 7-8 DIV and 14 DIV) or two hours (other time points) at $37^{\circ} \mathrm{C}$ in a cell incubator then $3 \times 150 \mu 1$ per culture well were transferred into a P96 plate (Corning, USA). Absorbance was measured at $490 \mathrm{~nm}$ via a microplate spectrophotometer (SpectraMax i3, Molecular Devices) and the SoftMax Pro software (Molecular Devices). The mean result of three technical replicates was considered as $n=1$ biological replicate. To assay cell death, the release of lactate dehydrogenase (LDH) into the cell culture medium was 
quantified using the CytoTox 96 Non-radioactive Cytotoxicity Assay (Promega) following the manufacturer's instructions. Maximum LDH release was determined by adding lysis solution (9\% Triton X-100) to cells grown on coated glass. Briefly, 3 x $50 \mu 1$ of culture medium from each culture well were transferred into a P96 plate (Corning, USA). Reagent was added (1:1 ratio) and the cell culture medium samples were incubated during 30 minutes at room temperature. Then 1 volume of stop reaction buffer was added. Absorbance was measured at $490 \mathrm{~nm}$ via a microplate spectrophotometer and the SoftMax Pro software. The mean result of three technical replicates was considered as $n=1$ biological replicate. Significant differences between results obtained for cells grown on glass and results obtained for other substrates were examined using the nonparametric Mann-Whitney and Wilcoxon tests, and $p$-values $<0.05$ were considered significant.

\subsection{Cell culture imaging}

Cells were fixed with $4 \%$ formaldehyde. Cells were then permeabilised with a blocking buffer (PBS with 1\% bovine serum albumin and $0.1 \%$ Triton $\mathrm{X}-100$ ) for 10 minutes at room temperature, and incubated with NeuN (Millipore) and Homer1 (Synaptic System) antibodies diluted in blocking buffer overnight at $4^{\circ} \mathrm{C}$-followed by Alexa Flour 568- and 488-conjugated secondary antibodies (Invitrogen) for 3 hours at room temperature and dapi (Thermofischer). Immunolabelling was observed with an inverted confocal microscope (LSM 710, AxioObserver Zeiss) with a $\times 40$ lens. Images were processed with ZEN software (Zeiss). Figure 1 shows 10 $\mu \mathrm{m}$ orthogonal projections from the results.

\section{Results and discussion}

With reference to Table 1, three types of SU-8 were characterized in the study. First, SU-8 hard-baked for 2 hours at $100^{\circ} \mathrm{C}$, denoted 'S1', second, SU-8 hard-baked for 2 hours at $180^{\circ} \mathrm{C}$, denoted 'S2', and third, SU-8 hard-baked for 2 hours at $200^{\circ} \mathrm{C}$, denoted 'S3'. Note that we also tested SU-8 which had been hard-baked for a shorter time (15 minutes) at two different temperatures $\left(180^{\circ} \mathrm{C}\right.$ and $\left.200^{\circ} \mathrm{C}\right)$ that induced total cell death after 7 and 14 days respectively in vitro (DIV) although initially the cells adhered to SU-8 (data not shown here).

Metabolic activity assays, that directly reflect the living cell numbers, and cell death assay were performed at 7-8 DIV, 14 DIV, 21-22 DIV and 28 DIV (Fig. 1). Cells grown on glass disks were used as control samples. Additionally, we tested two other substrate materials commonly used to culture neural cells: tissue culture (TC) treated-polystyrene and PDMS. All the results from the different substrates were compared to those obtained using glass.

Primary cortical cells grown on TC treated-polystyrene and PDMS did not exhibit any significant differences compared to primary cortical cells grown on glass except cells grown on 
PDMS at 21 DIV (see Table 2 and Table 3). Moreover, using optical microscopy, the primary cortical cells appeared to be similar on all these substrates (data not shown). However the metabolic activity and cell death assays revealed, respectively, fewer living cells and increased level of dead cells at almost every stage for type S1 samples (Tables $2 \& 3$ ). After 21 DIV and $28 \mathrm{DIV}$, the mean metabolic activity exhibited by cortical cells grown on type S1 samples reached, respectively, $25.8 \%$ and $45.9 \%$ compared to cortical cells grown on glass, hence inferior to $50 \%$. This led us to conclude that hard baking at $100^{\circ} \mathrm{C}$ for 2 hours was not sufficient to make SU-8 biocompatible enough to support neuronal cell development.

For the type S2 and S3 samples, metabolic activity and cell death assays revealed fewer living cells at 7 DIV and 21 DIV and increased level of dead cells at 14 DIV and 21 DIV (see Table 2 and Table 3). After 21 DIV and 28 DIV, the mean metabolic activity exhibited by cortical cells grown on type S2 samples reached, respectively, $64.4 \%$ and $68.4 \%$ compared to cortical cells grown on glass and for cortical cells grown on type S3 samples reached, respectively, $71.5 \%$ and $79.4 \%$ so largely superior to $50 \%$. However, cortical cells grown on type S3 samples behaved quite differently from cells grown on glass, type S2 samples, or other substrates - they packed together and extend highly fasciculate neurites, a behavior typical of stressed neuronal cells. We also noted a highly variable level of cell death for cells grown on S2 samples at 28 DIV but no significant differences were observed with cells grown on glass at the same stage.

In parallel, we performed immunostainings of cortical cells at 23 DIV when rat cortical cells have been shown to be organized into functional networks - i.e. exhibiting synchronized bursting activity - through microelectrode array recordings (data not shown). Two neuronal proteins were stained: NeuN, a neuronal nuclear protein and Homer, a postsynaptic density scaffold protein involved in the targeting of glutamate receptors. This confirmed the observations made on living cells. Although neuronal cell bodies, visualized through NeuN staining, tend only partially to group together on glass or type S2 samples, neuronal cell bodies were heavily packed on type S3 samples (see Fig. 2). While dendritic arborization, visualized through Homer1 staining, was dense and distributed uniformly around neuronal cell bodies on glass or type S2 samples, dendritic arborization on type S3 samples was highly heterogeneousrevealing uneven neurite outgrowth (see Fig. 2). It is likely that hard-baking SU-8 at $200^{\circ} \mathrm{C}$ induces both detoxification of the photoresist supported by good results at viability tests and structure alteration that compromises neurite outgrowth but does not induce cell death.

In conclusion, our results suggest that the hard-baking of SU-8 photoresist for 2 hours at $180^{\circ} \mathrm{C}$ is enough to detoxify SU-8. One can suggest that the modified neuronal biocompatibility of the SU-8 with thermal treatment observed here is associated with the matter content of the SU-8 which is known to change with heating and outgassing [46]. Several species 
are outgassed from the SU-8 during heating-some or all of these species may be toxic to neurons. Further work is required to verify this. Then poly-D-lysine + laminin coating promotes neuronal cell adhesion on SU-8 although at an inferior level compared to coated-glass. Coupled together hard-baking and traditional coating used in cell biology lead to neuronal survival in a time scale compatible with the development of a functional neural network from primary neural cells. This protocol elicits comparable number of living primary neural cells in long-term cultures with previously published protocols - 3 weeks - including hard-baking for three days + sonication + parylene coating + traditional coating used in cell biology (poly-D-lysine) [36] and hard-baking for three days + surface structuration (high aspect ratio towers) + traditional coating used in cell biology (poly-L-lysine) [40]. However, we finish by noting that the compatibility of a $180^{\circ} \mathrm{C}$ hard-bake depends on the temperature sensitivity of the specific technological process employed by the engineer.

\section{Table 2}

Mean metabolic activity (reflecting living cell number) of primary cortical cells cultured on top of different substrates after 7-8, 14, 21-22 and 28 DIV. At least $n=3$ biological replicates for each condition. Significant differences between results obtained for cells grown on glass and results obtained for other substrates were examined using the nonparametric Mann-Whitney and Wilcoxon tests $(*: p<0.05$ and $* * *: p<0.005)$.

\begin{tabular}{|c|c|c|c|c|}
\hline Sample & $\begin{array}{c}\text { Mean metabolic } \\
\text { activity at 7-8 DIV }\end{array}$ & $\begin{array}{c}\text { Mean metabolic } \\
\text { activity at 14 DIV }\end{array}$ & $\begin{array}{c}\text { Mean metabolic } \\
\text { activity at 21-22 DIV }\end{array}$ & $\begin{array}{c}\text { Mean metabolic } \\
\text { activity at 28 DIV }\end{array}$ \\
\hline $\begin{array}{c}\text { Glass } \\
\text { (reference) }\end{array}$ & $100 \pm 8(n=8)$ & $100 \pm 8(n=9)$ & $100 \pm 18(n=6)$ & $100 \pm 21(n=6)$ \\
\hline $\begin{array}{c}\text { TC-treated } \\
\text { polystyrene }\end{array}$ & $120 \pm 37(n=10)$ & $109 \pm 24(n=11)$ & $116 \pm 13(n=7)$ & $136 \pm 28(n=7)$ \\
\hline PDMS & $115 \pm 42(n=6)$ & $124 \pm 46(n=6)$ & $130 \pm 13 *(n=4)$ & $132 \pm 17(n=4)$ \\
\hline SU-8 'S1' & $71 \pm 9 *(n=3)$ & $74 \pm 6 * * *(n=5)$ & $26 \pm 10 *(n=3)$ & $46 \pm 4 *(n=3)$ \\
\hline SU-8 'S2' & $73 \pm 18 *(n=6)$ & $95 \pm 43(n=8)$ & $64 \pm 19 *(n=6)$ & $68 \pm 51(n=6)$ \\
\hline SU-8 'S3' & $38 \pm 19 *(n=3)$ & $80 \pm 30(n=4)$ & $72 \pm 11 *(n=3)$ & $79 \pm 37(n=3)$ \\
\hline
\end{tabular}

\section{Table 3}

Mean mortality (ratio of cell death on metabolic activity) of primary cortical cells cultured on top of different substrates after 7-8, 14, 21-22 and 28 DIV. At least $n=3$ biological replicates for each condition. Significant differences between results obtained for cells grown on glass and results obtained for other substrates were examined using the nonparametric Mann-Whitney and Wilcoxon tests $(*: p<0.05, * *: p<0.01$ and $* * *: p<0.005)$. 


\begin{tabular}{|c|c|c|c|c|}
\hline Sample & $\begin{array}{c}\text { Mean cell mortality } \\
\text { at 7-8 DIV }\end{array}$ & $\begin{array}{c}\text { Mean cell mortality at } \\
14 \mathrm{DIV}\end{array}$ & $\begin{array}{c}\text { Mean cell mortality } \\
\text { at 21-22 DIV }\end{array}$ & $\begin{array}{c}\text { Mean cell mortality } \\
\text { at 28 DIV }\end{array}$ \\
\hline $\begin{array}{c}\text { Glass } \\
\text { (reference) }\end{array}$ & $30 \pm 13(n=8)$ & $27 \pm 4(n=9)$ & $22 \pm 6(n=6)$ & $33 \pm 20(n=6)$ \\
\hline $\begin{array}{c}\text { TC-treated } \\
\text { polystyrene }\end{array}$ & $26 \pm 7(n=10)$ & $30 \pm 5(n=11)$ & $22 \pm 7(n=7)$ & $23 \pm 10(n=7)$ \\
\hline PDMS & $37 \pm 12(n=6)$ & $32 \pm 15(n=6)$ & $19 \pm 8(n=4)$ & $22 \pm 9(n=4)$ \\
\hline SU-8 'S1' & $57 \pm 7 *(n=3)$ & $34 \pm 5 * * *(n=5)$ & $86 \pm 64 *(n=3)$ & $41 \pm 22(n=3)$ \\
\hline SU-8 'S2' & $49 \pm 22(n=6)$ & $37 \pm 15 *(n=8)$ & $38 \pm 13 *(n=6)$ & $80 \pm 74(n=6)$ \\
\hline SU8 'S3' & $31 \pm 21(n=3)$ & $42 \pm 16^{* *}(n=4)$ & $39 \pm 6 *(n=3)$ & $44 \pm 8(n=3)$ \\
\hline
\end{tabular}

a)

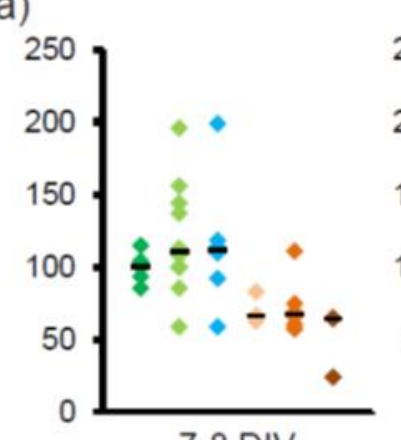

7-8 DIV

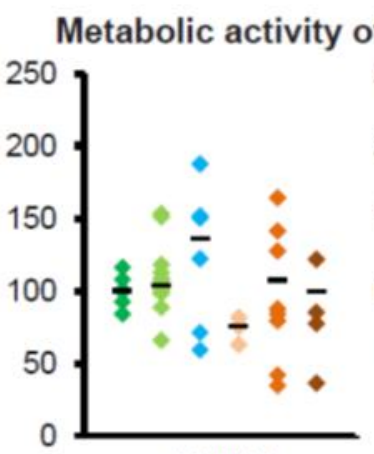

14 DIV

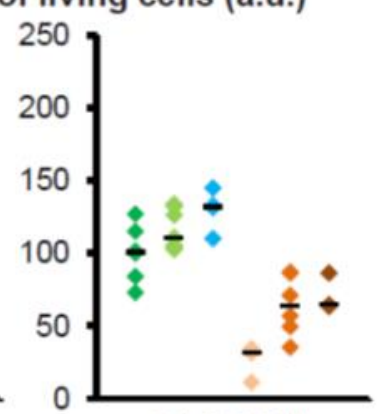

21-22 DIV

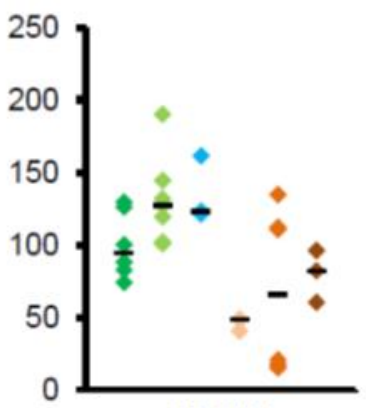

28 DIV

$\bullet$ Glass $\quad$ TC treated-Polystyrene $\bullet$ PDMS $\$$ S1 1 S2 43

b)

Cell death / metabolic activity ratio
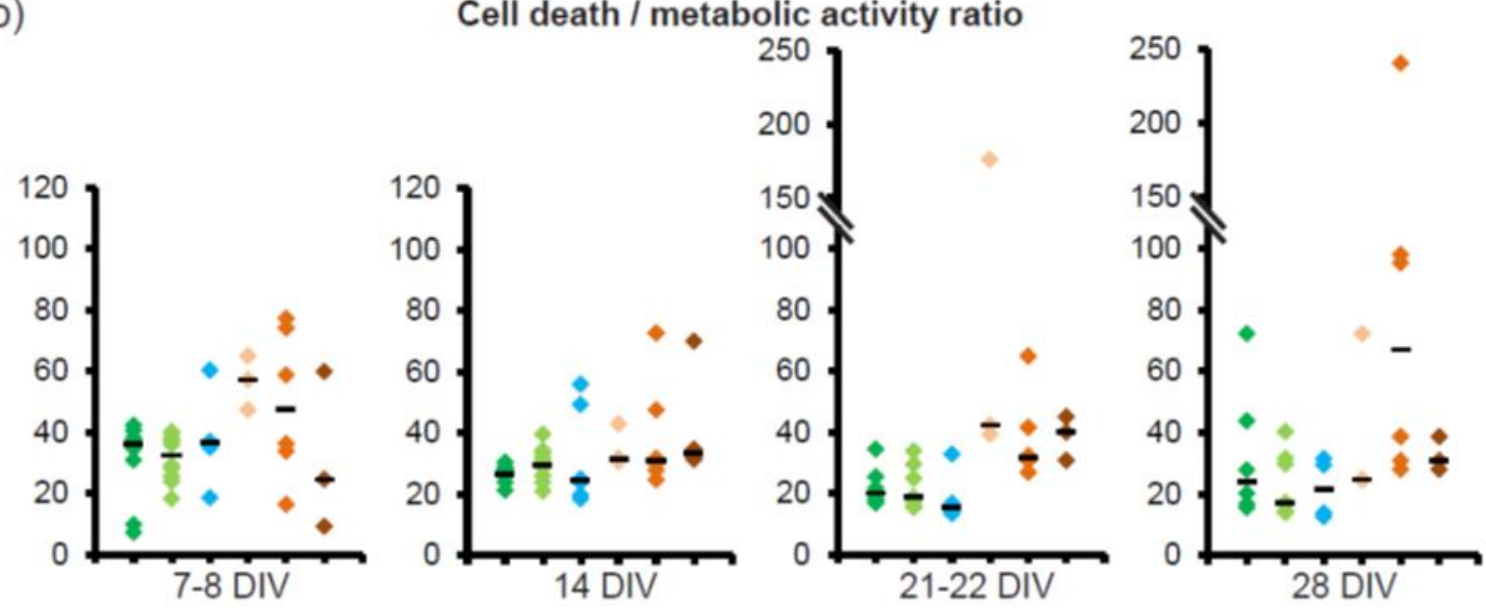

Fig. 1. Primary cortical cell biocompatibility of SU-8 hard-baked at different temperatures compared to materials commonly used for cell culture.

Comparison of the metabolic activity (reflecting living cell number, a) and the death (ratio of cell death on metabolic activity, b) of primary cortical cells cultured on top of different substrates after 7-8, 14, 21-22 and 28 DIV. Median values are indicated in black. At least $n=3$ biological replicates for each condition. 


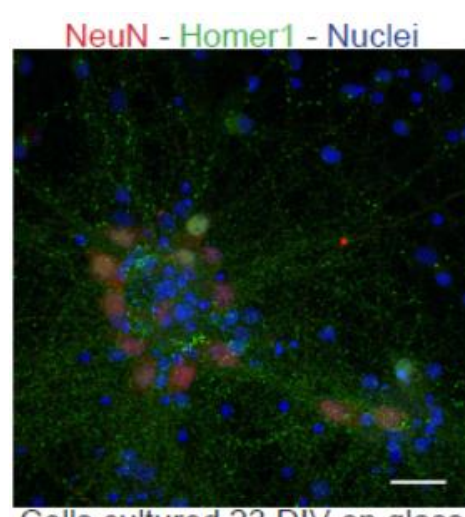

Cells cultured 23 DIV on glass

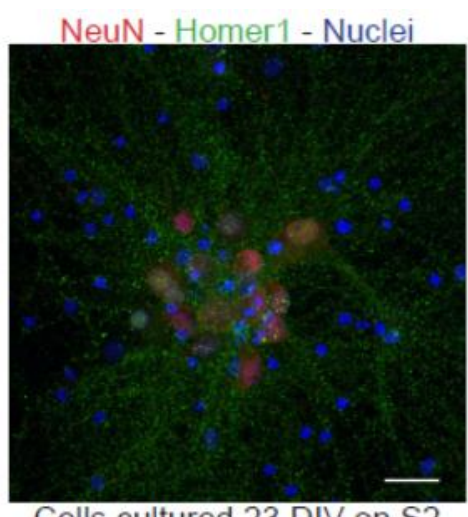

Cells cultured 23 DIV on S2

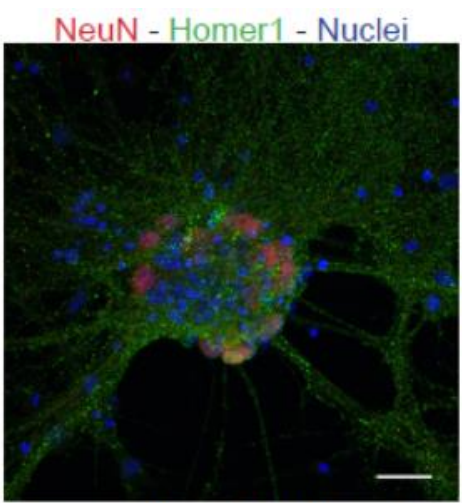

Cells cultured 23 DIV on S3

Fig. 2. Development of primary cortical cells on SU-8 hard-baked at different temperatures compared to glass.

Immunolabelling of primary cortical cells grown on glass (left), SU-8 hardbaked for 2 hours at $180^{\circ} \mathrm{C}$ (middle) and SU-8 hard-baked for 2 hours at $200^{\circ} \mathrm{C}$ (right). NeuN is stained in red, homer1, a post-synaptic protein, is stained in green and nuclei are in blue. Scale bars, $20 \mu \mathrm{m}$.

\section{Acknowledgements}

The work was partly supported by the French RENATECH network, the LabEx

DISTALZ and the Joint Inserm-University Chairs program. We thank Meryem Tardivel of the BICeL-Campus HU Facility for access to systems.

\section{Declaration of competing interest}

The authors declare no conflict of interest.

\section{References}

[1] A.C.R. Grayson, R.S. Shawgo, A.M. Johnson, N.T. Flynn, Y. Li, M.J. Cima, R. Langer, A BioMEMS Review: MEMS Technology for Physiologically Integrated Devices, Proc. IEEE. 92 (2004) 6-21. https://doi.org/10.1109/JPROC.2003.820534.

[2] R. Bashir, BioMEMS: state-of-the-art in detection, opportunities and prospects, Adv. Drug Deliv. Rev. 56 (2004) 1565-1586. https://doi.org/10.1016/j.addr.2004.03.002.

[3] Z. Xu, P. Fang, B. Xu, Y. Lu, J. Xiong, F. Gao, X. Wang, J. Fan, P. Shi, High-throughput three-dimensional chemotactic assays reveal steepness-dependent complexity in neuronal sensation to molecular gradients, Nat. Commun. 9 (2018) 4745. https://doi.org/10.1038/s41467-018-07186-x.

[4] J. Courte, R. Renault, A. Jan, J.-L. Viovy, J.-M. Peyrin, C. Villard, Reconstruction of directed neuronal networks in a microfluidic device with asymmetric microchannels, in: 
Methods Cell Biol., Elsevier, 2018: pp. 71-95.

https://doi.org/10.1016/bs.mcb.2018.07.002.

[5] A. Virlogeux, E. Moutaux, W. Christaller, A. Genoux, J. Bruyère, E. Fino, B. Charlot, M. Cazorla, F. Saudou, Reconstituting Corticostriatal Network on-a-Chip Reveals the Contribution of the Presynaptic Compartment to Huntington's Disease, Cell Rep. 22 (2018) 110-122. https://doi.org/10.1016/j.celrep.2017.12.013.

[6] V. Radotić, D. Braeken, P. Drviš, M. Mattotti, D. Kovačić, Advantageous environment of micro-patterned, high-density complementary metal-oxide-semiconductor electrode array for spiral ganglion neurons cultured in vitro, Sci. Rep. 8 (2018) 7446. https://doi.org/10.1038/s41598-018-25814-w.

[7] H. Lorenz, M. Despont, N. Fahrni, N. LaBianca, P. Renaud, P. Vettiger, SU-8: a low-cost negative resist for MEMS, J Micromech Microeng. 7 (1997) 121-124.

[8] J. Zhang, K.L. Tan, H.Q. Gong, Characterization of the polymerization of SU-8 photoresist and its applications in micro-electro-mechanical systems (MEMS), Polym. Test. 20 (2001) 693-701. https://doi.org/10.1016/S0142-9418(01)00005-8.

[9] C.H. Smith, A. Sklavonuos, N.S. Barker, SU-8 micromachining of millimeter and submillimeter waveguide circuits, in: 2009 IEEE MTT- Int. Microw. Symp. Dig., IEEE, Boston, MA, USA, 2009: pp. 961-964. https://doi.org/10.1109/MWSYM.2009.5165858.

[10] T. Baetens, E. Pallecchi, V. Thomy, S. Arscott, Metallized SU-8 thin film patterns on stretchable PDMS, J. Micromechanics Microengineering. (2019). https://doi.org/10.1088/1361-6439/ab307f.

[11] J. Carlier, S. Arscott, V. Thomy, J.C. Fourrier, F. Caron, J.C. Camart, C. Druon, P. Tabourier, Integrated microfluidics based on multi-layered SU-8 for mass spectrometry analysis, J Micromech Microeng. 14 (2004) 619-624.

[12] P. Abgrall, V. Conedera, H. Camon, A.-M. Gue, N.-T. Nguyen, SU-8 as a structural material for labs-on-chips and microelectromechanical systems, Electrophoresis. 28 (2007) 4539-4551. https://doi.org/10.1002/elps.200700333.

[13] S. Arscott, SU-8 as a material for lab-on-a-chip-based mass spectrometry, Lab. Chip. 14 (2014) 3668-3689. https://doi.org/10.1039/C4LC00617H.

[14] S. Arscott, S. Le Gac, C. Druon, P. Tabourier, C. Rolando, A planar on-chip micro-nib interface for NanoESI-MS microfluidic applications, J Micromech Microeng. 14 (2004) 310-316.

[15] S. Tuomikoski, T. Sikanen, R.A. Ketola, R. Kostiainen, T. Kotiaho, S. Franssila, Fabrication of enclosed SU-8 tips for electrospray ionization-mass spectrometry, Electrophoresis. 26 (2005) 4691-4702. https://doi.org/10.1002/elps.200500475.

[16] D.L. Herbertson, C.R. Evans, N.J. Shirtcliffe, G. McHale, M.I. Newton, Electrowetting on superhydrophobic SU-8 patterned surfaces, Sens. Actuators Phys. 130-131 (2006) 189-193. https://doi.org/10.1016/j.sna.2005.12.018.

[17] G. Blagoi, S. Keller, A. Johansson, A. Boisen, M. Dufva, Functionalization of SU-8 photoresist surfaces with IgG proteins, Appl. Surf. Sci. 255 (2008) 2896-2902. https://doi.org/10.1016/j.apsusc.2008.08.089.

[18] B.-H. Jo, L.M. Van Lerberghe, K.M. Motsegood, D.J. Beebe, Three-dimensional microchannel fabrication in polydimethylsiloxane (PDMS) elastomer, J. Microelectromechanical Syst. 9 (2000) 76-81. https://doi.org/10.1109/84.825780.

[19] S. Natarajan, D.A. Chang-Yen, B.K. Gale, Large-area, high-aspect-ratio SU-8 molds for the fabrication of PDMS microfluidic devices, J. Micromechanics Microengineering. 18 (2008) 045021. https://doi.org/10.1088/0960-1317/18/4/045021.

[20] E. Peltola, J.J. Heikkinen, K. Sovanto, S. Sainio, A. Aarva, S. Franssila, V. Jokinen, T. Laurila, SU-8 based pyrolytic carbon for the electrochemical detection of dopamine, J. Mater. Chem. B. 5 (2017) 9033-9044. https://doi.org/10.1039/C7TB02469J.

[21] S. Chung, S. Park, Effects of temperature on mechanical properties of SU-8 photoresist material, J. Mech. Sci. Technol. 27 (2013) 2701-2707. https://doi.org/10.1007/s12206013-0714-6. 
[22] G. Kotzar, M. Freas, P. Abel, A. Fleischman, S. Roy, C. Zorman, J.M. Moran, J. Melzak, Evaluation of MEMS materials of construction for implantable medical devices, Biomaterials. 23 (2002) 2737-2750. https://doi.org/10.1016/S0142-9612(02)00007-8.

[23] S.-H. Cho, H.M. Lu, L. Cauller, M.I. Romero-Ortega, J.-B. Lee, G.A. Hughes, Biocompatible SU-8-Based Microprobes for Recording Neural Spike Signals From Regenerated Peripheral Nerve Fibers, IEEE Sens. J. 8 (2008) 1830-1836. https://doi.org/10.1109/JSEN.2008.2006261.

[24] M. Hennemeyer, F. Walther, S. Kerstan, K. Schürzinger, A.M. Gigler, R.W. Stark, Cell proliferation assays on plasma activated SU-8, Microelectron. Eng. 85 (2008) 12981301. https://doi.org/10.1016/j.mee.2008.01.026.

[25] E.S. Ereifej, S. Khan, G. Newaz, J. Zhang, G.W. Auner, P.J. VandeVord, Characterization of astrocyte reactivity and gene expression on biomaterials for neural electrodes, J. Biomed. Mater. Res. A. 99A (2011) 141-150. https://doi.org/10.1002/jbm.a.33170.

[26] K.V. Nemani, K.L. Moodie, J.B. Brennick, A. Su, B. Gimi, In vitro and in vivo evaluation of SU-8 biocompatibility, Mater. Sci. Eng. C. 33 (2013) 4453-4459. https://doi.org/10.1016/j.msec.2013.07.001.

[27] T. Zhou, S.F. Perry, Y. Berdichevsky, S. Petryna, V. Fluck, S. Tatic-Lucic, Multielectrode array capable of supporting precisely patterned hippocampal neuronal networks, Biomed. Microdevices. 17 (2015) 2. https://doi.org/10.1007/s10544-0149907-8.

[28] E. Kim, S.-J. Yoo, E. Kim, T.-H. Kwon, L. Zhang, C. Moon, H. Choi, Nano-patterned SU-8 surface using nanosphere-lithography for enhanced neuronal cell growth, Nanotechnology. 27 (2016) 175303. https://doi.org/10.1088/0957-4484/27/17/175303.

[29] E. Kim, J.-Y. Kim, H. Choi, An SU-8-based microprobe with a nanostructured surface enhances neuronal cell attachment and growth, Micro Nano Syst. Lett. 5 (2017) 28. https://doi.org/10.1186/s40486-017-0062-x.

[30] A. Ajetunmobi, D. McAllister, N. Jain, O. Brazil, A. Corvin, Y. Volkov, D. Tropea, A. Prina-Mello, Characterization of SH-SY5Y human neuroblastoma cell growth over glass and SU-8 substrates: CHARACTERIZATION OF SH-SY5Y HUMAN NEUROBLASTOMA CELL GROWTH, J. Biomed. Mater. Res. A. 105 (2017) 21292138. https://doi.org/10.1002/jbm.a.36071.

[31] D. Ito, T. Komatsu, K. Gohara, Measurement of saturation processes in glutamatergic and GABAergic synapse densities during long-term development of cultured rat cortical networks, Brain Res. 1534 (2013) 22-32. https://doi.org/10.1016/j.brainres.2013.08.004.

[32] E.M. Abdulla, I.C. Campbell, Studies of Neurotoxicity in Cellular Models, in: Vitro Methods Pharm. Res., Elsevier, 1997: pp. 155-180. https://doi.org/10.1016/B978012163390-5.50008-9.

[33] J. Gordon, S. Amini, M.K. White, General Overview of Neuronal Cell Culture, in: S. Amini, M.K. White (Eds.), Neuronal Cell Cult., Humana Press, Totowa, NJ, 2013: pp. 1-8. https://doi.org/10.1007/978-1-62703-640-5_1.

[34] K.T. LePage, R.W. Dickey, W.H. Gerwick, E.L. Jester, T.F. Murray, On the Use of Neuro-2a Neuroblastoma Cells Versus Intact Neurons in Primary Culture for Neurotoxicity Studies, Crit. Rev. Neurobiol. 17 (2005) 27-50. https://doi.org/10.1615/CritRevNeurobiol.v17.i1.20.

[35] M. Heravi, L. Dargahi, S. Parsafar, A. Tayaranian Marvian, F. Aliakbari, D. Morshedi, The primary neuronal cells are more resistant than PC12 cells to $\alpha$-synuclein toxic aggregates, Neurosci. Lett. 701 (2019) 38-47. https://doi.org/10.1016/j.neulet.2019.01.055.

[36] V.N. Vernekar, D.K. Cullen, N. Fogleman, Y. Choi, A.J. García, M.G. Allen, G.J. Brewer, M.C. LaPlaca, SU-8 2000 rendered cytocompatible for neuronal bioMEMS applications, J. Biomed. Mater. Res. A. 89 (2008) 138-151. https://doi.org/10.1002/jbm.a.31839. 
[37] Y. Ren, S.-H. Huang, S. Mosser, M. Heuschkel, A. Bertsch, P. Fraering, J.-J. Chen, P. Renaud, A Simple and Reliable PDMS and SU-8 Irreversible Bonding Method and Its Application on a Microfluidic-MEA Device for Neuroscience Research, Micromachines. 6 (2015) 1923-1934. https://doi.org/10.3390/mi6121465.

[38] M. Stangegaard, Z. Wang, J.P. Kutter, M. Dufva, A. Wolff, Whole genome expression profiling using DNA microarray for determining biocompatibility of polymeric surfaces, Mol. Biosyst. 2 (2006) 421. https://doi.org/10.1039/b608239d.

[39] M. Marelli, G. Divitini, C. Collini, L. Ravagnan, G. Corbelli, C. Ghisleri, A. Gianfelice, C. Lenardi, P. Milani, L. Lorenzelli, Flexible and biocompatible microelectrode arrays fabricated by supersonic cluster beam deposition on SU-8, J. Micromechanics Microengineering. 21 (2011) 045013. https://doi.org/10.1088/0960-1317/21/4/045013.

[40] Y. Choi, R. Powers, V. Vernekar, A.B. Frazier, M.C. LaPlaca, M.G. Allen, High Aspect Ratio SU-8 Structures for 3-D Culturing of Neurons, in: Microelectromechanical Syst., ASME, Washington, DC, USA, 2003: pp. 651-654. https://doi.org/10.1115/IMECE2003-42794.

[41] Z.-Z. Wu, Y. Zhao, W.S. Kisaalita, Interfacing SH-SY5Y human neuroblastoma cells with SU-8 microstructures, Colloids Surf. B Biointerfaces. 52 (2006) 14-21. https://doi.org/10.1016/j.colsurfb.2006.06.001.

[42] S.L. Tao, K.C. Popat, J.J. Norman, T.A. Desai, Surface Modification of SU-8 for Enhanced Biofunctionality and Nonfouling Properties, Langmuir. 24 (2008) 2631-2636. https://doi.org/10.1021/la703066z.

[43] R. Seghir, S. Arscott, Extended PDMS stiffness range for flexible systems, Sens. Actuat A. 230 (2015) 33-39.

[44] M. Gaudet, S. Arscott, A user-friendly guide to the optimum ultraviolet photolithographic exposure and greyscale dose of SU-8 photoresist on common MEMS, microsystems, and microelectronics coatings and materials, Anal Methods. (n.d.) 24952504.

[45] M.-C. Galas, P. Dourlen, S. Bégard, K. Ando, D. Blum, M. Hamdane, L. Buée, The Peptidylprolyl cis/trans -Isomerase Pin1 Modulates Stress-induced Dephosphorylation of Tau in Neurons: IMPLICATION IN A PATHOLOGICAL MECHANISM RELATED TO ALZHEIMER DISEASE, J. Biol. Chem. 281 (2006) 19296-19304. https://doi.org/10.1074/jbc.M601849200.

[46] J. Melai, C. Salm, R. Wolters, J. Schmitz, Qualitative and quantitative characterization of outgassing from SU-8, Microelectron. Eng. 86 (2009) 761-764.

https://doi.org/10.1016/j.mee.2008.11.008. 